\title{
Article \\ Harvesting Technologies and Costs of Biomass Production from Energy Crops Cultivated on Farms in the Małopolska Region
}

\author{
Dariusz Kwaśniewski ${ }^{1}$, Aleksandra Płonka ${ }^{2}$ [D and Paweł Mickiewicz ${ }^{3, *}$ \\ 1 Department of Production Engineering, Logistics and Applied Computer Science, Faculty of Production and \\ Power Engineering, University of Agriculture in Krakow, 30-149 Krakow, Poland; \\ dariusz.kwasniewski@urk.edu.pl \\ 2 Department of Economics and Food Economy, Faculty of Agriculture and Economics, \\ University of Agriculture in Krakow, 31-120 Krakow, Poland; a.plonka@ur.krakow.pl \\ 3 Department of Management, Faculty of Economics, West Pomeranian University of Technology Szczecin, \\ 71-210 Szczecin, Poland \\ * Correspondence: pmickiewicz@zut.edu.pl
}

check for updates

Citation: Kwaśniewski, D.; Płonka, A.; Mickiewicz, P. Harvesting Technologies and Costs of Biomass Production from Energy Crops Cultivated on Farms in the Małopolska Region. Energies 2022, 15, 131. https://doi.org/10.3390/ en15010131

Academic Editor:

Alberto-Jesus Perea-Moreno

Received: 14 November 2021

Accepted: 22 December 2021

Published: 24 December 2021

Publisher's Note: MDPI stays neutral with regard to jurisdictional claims in published maps and institutional affiliations.

Copyright: (C) 2021 by the authors. Licensee MDPI, Basel, Switzerland. This article is an open access article distributed under the terms and conditions of the Creative Commons Attribution (CC BY) license (https:// creativecommons.org/licenses/by/ $4.0 /)$.

\begin{abstract}
This study aimed to assess biomass production costs from perennial energy crops, such as Miscanthus giganteus, Sida hermaphrodita, and coppiced willow, in selected agricultural holdings. This assessment was based on applied technologies for harvesting the biomass of the energy crops mentioned above. The scope of the study included research on ten farms located in Małopolska and establishing the possibility of biomass production from selected energy crops in these entities. Biomass production costs have been estimated using the computer application "Bioalkylation". The result of the research was the answer to the question: what can be the cost range of biomass production from perennial energy crops for the crops Miscanthus giganteus, Sida hermaphrodita, and coppiced willow as the most popular plants? The study shows that production costs depend primarily on the harvesting technology used and the machinery used in the farm. The harvest with rotary mowers, small presses, and windrows was applied regarding Miscanthus giganteus and Sida hermaphrodita. The costs of biomass production were, on average, $424.7 \mathrm{EUR} \mathrm{ha}^{-1}$ for Miscanthus giganteus and 278.9 EUR $\mathrm{ha}^{-1}$ for Sida hermaphrodita. Concerning tonne, this was $37.6 \mathrm{EUR} \mathrm{t}^{-1}$ for Miscanthus giganteus and 30.0 EUR $^{-1}$ for Sida hermaphrodita, respectively. In the case of harvesting energy willow, in the form of whole shoots, inefficient and labour-intensive technologies using chainsaws and combustion cutters were applied. The biomass production costs were thus the highest among the assessed plants and amounted, on average, to $612.1 \mathrm{EUR} \mathrm{ha}^{-1}$, which in terms of tonne corresponded to a value of 30.6 EUR. The obtained results and the analysis presented in the paper may help in planning the cultivation of perennial energy crops in order to obtain biomass used for heating purposes on a farm.
\end{abstract}

Keywords: biomass; production costs; Miscanthus giganteus; honeysuckle; energy willow; agricultural holding

\section{Introduction}

The foundation of the economy of the super-industrial era is still fossil fuels, the use of which has steadily increased since the industrial revolution in Europe [1]. Half of the total energy consumption of the last two thousand years was consumed by humankind during the last century of this period [2]. Unfortunately, with successive decades, this disparity has intensified and the need for constant energy consumption has grown to become the biggest addiction of modern civilisation. According to the BP Statistical Review of World Energy report [3], the world consumed over 14,000 Mtoe in 2019, and global consumption is growing at a rate of $178 \mathrm{Mtoe} /$ year. The World Counts industry portal alerts that modern civilisation is acquiring so many resources that continuing these trends will soon require a second Earth [4]. Conventional energy resources like carbon, natural gas, and oil are no longer sufficient to satisfy the global economy's demand [5]. Experts warn that with the 
current energy consumption, non-renewable resources may be used up as soon as 2040 [6]. Power generation in Poland is mainly based on the combustion of hard coal and lignite; therefore, as the probability of their exhaustion seems natural and to meet the obligations towards the European Union, the government of Poland should intensify its actions to promote renewable energy sources (RES) in the country [7].

One of the most popular and used renewable energy sources is undoubtedly biomass [8]. Biomass includes raw materials of plant and animal origin, which are biodegradable and come from agricultural production and the agri-food industry, as well as from forestry and related branches of the economy. According to the provisions of Directive 2009/28/EC of the European Parliament and of the Council of 23 April 2009, the term 'biomass' means the biodegradable fraction of products, waste, or residues of biological origin from agriculture (including vegetal and animal substances), forestry and related industries including fisheries and aquaculture, as well as the biodegradable fraction of industrial and municipal waste [9].

The most popular and used source of biomass is energy crops. Energy crops are grown on agricultural land and are processed into biofuels and biocomponents, heat, or electricity. In the climatic conditions of Poland, the raw material base of biomass produced for energy purposes can be categorized into three groups of plants:

trees and shrubs: willow (Salix L.), poplar (Populus L.), robinia acacia (Robinia pseudoacacia L.), multiflora rose (Rosa multiflora);

grasses: Miscanthus x giganteus (Miscanthus x giganteus J.M. Greef M. Deuter), Miscanthus sinensis Andersson, Miscanthus sacchariflorus Maxim Hack, Spartina prairie (Spartina pectinata Bosc ex Link);

perennial plants: Pennsylvania hemlock (Sida hermaphrodita Rusby L.), Japanese knotweed (Reynoutria japonica Houtt), Sakhalin knotweed (Reynoutria sachalinensis), perennial bindweed (Silphium perfoliatum), Jerusalem artichoke (Helianthus tuberosus) [10].

The use of biomass from field crops is beneficial regarding energy and the environment [11-13]; however, the current economy limits the possibility of its use on a broader scale for economic reasons. It should be emphasised that these crops can activate rural areas and allow the possibility to manage soils not used for agriculture and wastelands [14-18].

\section{Fundamentals of Perennial Energy Crop Production}

The perennial energy crops that enjoy the most significant popularity in Poland are energy willow, Pennsylvania sida, and Miscanthus giganteus. Willow in Poland commonly grows on the edges of watercourses and wetlands. It occurs in tree and shrub forms, and a change in form may occur due to cultivation. The most popular species used for energy purposes is the willow wicker, also called hemp willow, characterised by fast biomass growth and resistance to pests and diseases $[19,20]$.

Honeysuckle willow, in cultivation for energy purposes, is harvested in one-, two- or three-year cycles. Depending on site and age, shoots reach up to $6 \mathrm{~m}$ in height and $80 \mathrm{~mm}$ in diameter. The intense green leaves, lanceolate in shape with a prominent yellow nerve, are $80-250 \mathrm{~mm}$ long and 6-12 $\mathrm{mm}$ wide. The inflorescences are cylindrical catkins that flower before the leaves develop [21]. Willow is propagated vegetatively using pieces of cut stem called cuttings or, more commonly, stobras. Their length should be between 200 and $250 \mathrm{~mm}$ with a thickness of 5-12 $\mathrm{mm}$, and the thickness in the centre should not be less than $7 \mathrm{~mm}[22,23]$.

The most suitable sites for willow cultivation are soils of bonitation classes III, IV, and V with sufficient moisture [24]. Precipitation in willow cultivation is significant in the spring period, as lack of precipitation can result in plant loss. Lack of water limits the development of the root system of young plants. Therefore, willow cultivation must be carried out in soils with adequate groundwater levels ranging from 1 to $1.5 \mathrm{~m}$, depending on their permeability. For complete and intensive growth, willow needs a minimum of $500 \mathrm{~mm}$ of rainfall, and the moisture accumulated in the soil after winter is also necessary [17]. 
When planning willow plantings, consideration should be given to the harvesting system envisaged: single or two-phase. Machine harvesting requires heavy machinery to enter the field without damaging the freshly cut willow crowns with its wheels. For single-phase harvesting, the willow is planted in strips. Two rows are planted at a spacing of $0.75-0.8 \mathrm{~m}$ and a belt spacing of $1.25-1.5 \mathrm{~m}$. The distance between plants in a row is $0.4-0.5 \mathrm{~m}$. For two-phase harvesting, a row spacing of $0.7-0.8 \mathrm{~m}$ and a distance between plants in rows of $0.4-0.45 \mathrm{~m}$ is recommended [25-27].

Under Polish climatic conditions, willow is best harvested from mid-November to mid-March, after the plants have finished their vegetation period and leaves have fallen from shoots. Still, weather conditions do not always allow the harvest to be completed in this period. At this time, the moisture content of the wood is around $45-55 \%$, depending on the rotation, variety, region, and weather conditions. Under favourable climatic and soil conditions for willow cultivation and high mineral fertilisation, some short-rotation plants yield $20 \mathrm{td}$.m. ha ${ }^{-1}$. Usually, the yield of these plants is 8-12 $\mathrm{t} \mathrm{d.m.} \mathrm{ha}{ }^{-1}$ [22].

Pennsylvania honeysuckle is also called sida from the Latin name Sida hermaphrodita or Virginia mallow and is erroneously referred to as Pennsylvania mallow. The plant is native to North America and currently occurs in natural habitats in the central part of the eastern belt of the continent. A great interest in mallow in Poland appeared with the idea of using the biomass of this plant for energy purposes [28].

As a perennial plant, Pennsylvania honeysuckle develops a robust root system that, after a few years, can reach a depth of $2.5-3.0 \mathrm{~m}$ and grow horizontally to a diameter of 0.7-1.0 m. However, the main number of roots is in the layer at a depth of 0.3-0.4 m. In the horizontally growing roots, just below the soil surface, growth buds form from which new shoots grow in spring [28,29]. Mallow can be propagated both generatively by seeds and vegetatively using cuttings obtained by division of roots, shoots, or carpels. The optimum planting density for plants grown for dry stems on good soils can be considered $30-40$ thousand plants ha ${ }^{-1}$; on worse sites; it should be $50-60$ thousand plants ha ${ }^{-1}$. When grown for green mass (biogas), a higher planting density is recommended [10].

Sida hermaphrodita does not have special soil requirements. It grows in all types of soils, even in sandy soils of bonitation class $\mathrm{V}$, provided that they are moisturised. When growing mullein for energy purposes or for obtaining seeds, it should be remembered that plantations will last not 3-4 years (fodder use) but 15-20 years [29]. Seed sowing is carried out from April, when the top layer of soil reaches $8-10{ }^{\circ} \mathrm{C}$, in rows with a spacing of 0.6 $\times 0.7 \mathrm{~m}$ at a depth of $10-15 \mathrm{~mm}$. Root cuttings, i.e., root sections with growth buds, are planted in rows every $0.24-0.48 \mathrm{~m}$ at a row spacing of $0.70 \mathrm{~m}$ or $0.28-0.56 \mathrm{~m} \times 0.60 \mathrm{~m}$. The seedlings are best prepared just before planting [30].

The mullein biomass for burning should be harvested from late autumn to early spring. Studies conducted at the Institute of Soil Science and Plant Cultivation-Polish Research Institute (IUNG-PIB) indicate that the yield of mullein is mainly affected by plant density. At the density of 10 thousand per hectare, irrespective of the soil quality, the average yield of dry matter of mullein for 4 years was about $9.5 \mathrm{t} \mathrm{ha}^{-1}$, while in particular years, it ranged from 7.9 to $11.4 \mathrm{t} \mathrm{ha}^{-1}$. However, at the density of 20 thousand per hectare, the average yield for 4 years on heavy soil was 18.0, and on light soil-16.4 tha ${ }^{-1}$ [31].

Miscanthus giganteus is a perennial bunchgrass in the panicle family, native to Southeast Asian countries. It is erroneously called elephant grass, which is a typical African grass. For energy purposes, giant Miscanthus giganteus (Miscanthus giganteus $\times$ giganteus) is most commonly grown, which was bred by crossing Chinese Miscanthus giganteus (otherwise known as Japanese Miscanthus giganteus) and sugar Miscanthus giganteus [32]. Miscanthus giganteus is a perennial plant that produces underground rhizomes. It is characterised by a very extensive root system, reaching up to $2.5 \mathrm{~m}$ deep into the soil. As a result, it quickly and efficiently absorbs water and nutrients from the soil [33]. This grass forms large clumps, and the usable yield is thick stalks filled with a spongy core of $200-350 \mathrm{~cm}$ in height, the number of which per plant can reach 200. Diameter ranges from a few to more 
than $10 \mathrm{~mm}$ [10]. The plant has leaf blades of a light or dark green colour, lanceolate, is $0.6^{-1} \mathrm{~m}$ long and 8-32 $\mathrm{mm}$ wide [34].

Miscanthus giganteus can be grown in soils of V and VI class with adequate humidity and $\mathrm{pH}$, which should be around 6.5 [35]. In such soils, not very high yields should be expected. In soils richer in humus substances (III and IV classes) and with regulated water relations, yields can be obtained $20-30 \%$ higher than soils of lower bonitations [33]. Therefore, depending on habitat conditions, the yield of Miscanthus giganteus can be 10-30 $\mathrm{tha}^{-1}$ of dry biomass. Miscanthus giganteus seedlings are planted at a spacing of $1 \times 1 \mathrm{~m}$, allowing the plant to form large and dense clumps and ensuring optimal canopy penetration by light radiation. Miscanthus giganteus plants are less resistant to low temperatures, especially in the first year of cultivation. Therefore, it is recommended to protect the plantation for winter, e.g., by mulching or performing plant edging [36].

As in the case of all perennial plants, the preparation of the site before establishing the target Miscanthus giganteus plantation is the critical factor determining the success of cultivation. Depending on the cultural status of the soil on which the plantation is to be established, such cultivation treatments should be carried out that will enable its careful preparation [10]. It is crucial to weed the field before establishing the plantation thoroughly and perform soil chemical analyses to properly determine the need for liming and fertilisation with phosphorus and potassium [32]. The costs of tending a Miscanthus giganteus plantation are meagre. In the first year, mechanical weeding is carried out in the rows and between rows, using standard inter-row cultivations [37]. In the following years, an even Miscanthus giganteus canopy reduces weed growth. Before winter, in the first year after plantation establishment, it is necessary to protect plants against frost. A good solution may be to cut the first year's offshoots at the height of 8-10 cm above the ground and leave them on the field surface or mulch the plantation with straw [31,37].

Miscanthus giganteus can be harvested in late autumn with field forage harvesters, but this yields biomass with a moisture content of $35-55 \%$, depending on the genotype and year, which is not very useful for transport and storage. Postponing the harvest to early spring makes it possible to obtain biomass with $20-30 \%$ moisture content. The equipment used for harvesting hay or straw may then be used for harvesting Miscanthus giganteus. Miscanthus giganteus biomass with a moisture content of around $20 \%$ can be compacted, facilitating transport and storage. However, a lower yield of about $25 \%$ is obtained in spring [31].

The choice of technology for harvesting energy crops depends on their types. Fastgrowing shrubs and trees, including willow wattle, multiflorous rose, poplar, and acacia robinia, can be harvested in one or two stages in one-year cycles or more often in multiyear cycles $[22,32,38]$. The shrubs of multiflowered rose and acacia robinia, as well as perennials (Pennsylvania hemlock, tuberous sunflower), perennial grasses (Miscanthus giganteus, knapweed millet, prairie spartina, Gerard's palm) and reed canarygrass can also be harvested in one or two stages, but only in one-year cycles.

Single-stage harvesting involves simultaneous cutting and shredding of the plants, usually using a field chopper, either tractor- or self-propelled. The logical consequence of this is that it is also harvests plants in the form of chips (shrubs and trees) or chaff (grasses and perennials).

The two-stage harvesting involves two independent phases in which separate machines carry out the operations. In the first phase, the plants are cut, and in the second phase, they are chopped. The distinction between these phases is based on the form of the raw material or product to be obtained. There may be several operations between these phases, depending on the type of plant and the form of material to be cut. Concerning short-rotation plants, two-stage harvesting is dominated by harvesting whole plants and then, after the material has dried, shredding it under stationary conditions.

Grasses and perennials, after being cut, are harvested with balers or collecting trailers. Generally, it can be stated that harvesting grass plants or perennials can be carried out with machines commonly used to harvest green fodder, hay, or straw [38]. The size of the 
plantation largely determines the choice of harvesting technology, the form of raw material obtained (e.g., chips, whole stems, chopped straw, pressed straw), and if owned or rented harvesting machinery is used $[39,40]$.

Harvesting technologies for energy crops have gone through various stages of evolutionary development. Although the theoretical possibilities of applying modern harvesting technologies are extensive, very diverse mowing and processing biomass techniques are still used in practice. It is especially true for Polish conditions, where the cultivation of energy crops is very dispersed, and the areas of individual plantations are highly diverse, ranging from a few acres to several hundred hectares [38].

Production of biomass from energy crops is related to production costs and economic calculation. Due to the immense diversity of plants grown for energy purposes and their intended use, it is complicated to calculate such an economic impact. Regarding plants, which are used to produce biogas and liquid fuels, it can be noted that the income and costs of their products are very similar to those incurred in production for food purposes. The situation is quite different concerning perennial plantations, as these plants have a different agrotechnology, production cycle, and way of storage and sale. Establishing and maintaining such plantations is very difficult and gives rise to many concerns about the profitability of production and competitiveness in the marketplace relating to other agricultural crops.

It is crucial to carry out a thorough analysis and preliminary calculation before establishing an energy plantation. This task is quite difficult because the resource of initial data on the norms of consumption of production means, labour input, yield, or sale prices is relatively limited [41-43].

The primary cost carriers to produce biomass from energy crops are:

machinery park operating costs-these include maintenance and use costs of machinery; maintenance costs (fixed costs)—including depreciation, insurance, capital interest, and machinery storage; use costs (variable costs) arise from the use of machinery, including costs of energy carriers, repair, and maintenance costs;

labour costs (labour costs) - separated as a separate component (not included in machinery operating costs);

material costs-costs incurred because of the use of material (e.g., costs of purchasing seeds, seedlings, mineral, and organic fertilisers) other (indirect) costs-e.g., agricultural tax, and plantation insurance [35].

The cost intensity of biomass production for energy purposes is determined by the size of the yield and its price, the field area, and the harvesting technology. As the yield increases, the cost per unit mass decreases. Furthermore, modern machinery, with high efficiency, working in fields with a larger area, reduces costs significantly [44]. The selection [39,40] and operation of the machinery [45-47] used in biomass production processes also plays an essential role.

In the processes of biomass production from perennial energy crops, the following stages can be distinguished: establishment of the plantation, use (running the plantation), and plantation liquidation. The costs of biomass production are related to these stages, and an important assumption that should be considered in the cost calculations is the planned period of plantation use. The costs of establishment and decommissioning of a plantation, related to the years of its use, will allow the estimation of the average annual costs of running the plantation. In the costs of biomass production from perennial energy crops, an important role is played by harvesting costs, which are directly related to the applied harvesting technology.

In the Polish and foreign literature on the subject, there are no studies which would analyse the costs of biomass production from energy crops (e.g., Miscanthus giganteus, Sida hermaphrodita and coppiced willow) in a regional perspective, taking into account the harvesting technology used. Therefore, research in this direction is justified to show what the range of biomass production costs from selected perennial energy crops may be. 


\section{Research Methodology}

This study aimed to assess biomass production costs from perennial energy crops, i.e., energy willow, Sida hermaphrodita, and Miscanthus giganteus, which can be grown on selected farms. The production costs were given in monetary units of Euro, and the evaluation was based on the applied biomass harvesting technologies.

The subject scope of the study included ten agricultural holdings located in the Małopolska region. The selection of research subjects was based on the possibility of biomass production from selected energy crops occurring in these farms. The research took the form of an interview with the owner of the farm. During the interviews, information was obtained that characterised the farm, which was necessary for further analysis (Table 1). These data provided information on, among other things:

- the area of holding (utilised agricultural area),

- the area of the farm owner's dwelling to be heated,

- number of persons living in the dwelling,

- year of construction of the dwelling,

- the estimated efficiency of the heating installation of the residential building,

- types of tractors and agricultural machinery at the disposal of agricultural holding that can be used to harvest perennial energy crops (especially 'straw' crops, i.e., Miscanthus giganteus and Sida hermaphrodita)—agricultural tractors and balers, windrowers.

Table 1. Selected characteristics of the surveyed farms.

\begin{tabular}{|c|c|c|c|c|c|}
\hline Farm & $\begin{array}{c}\text { Utilised } \\
\text { Agricultural Area } \\
\text { (ha) }\end{array}$ & $\begin{array}{l}\text { Number of } \\
\text { Persons Forming } \\
\text { the Household }\end{array}$ & $\begin{array}{l}\text { Area of the } \\
\text { Residential } \\
\text { Building }\left(\mathrm{m}^{2}\right)\end{array}$ & $\begin{array}{l}\text { Year of } \\
\text { Construction of } \\
\text { the Dwelling }\end{array}$ & $\begin{array}{c}\text { Efficiency of the Heating } \\
\text { System of a Residential } \\
\text { Building }(\%)\end{array}$ \\
\hline 1 & 6.79 & 5 & 140 & 1999 & 70 \\
\hline 2 & 7.34 & 6 & 180 & 2010 & 80 \\
\hline 3 & 7.36 & 4 & 140 & 2002 & 70 \\
\hline 4 & 9.91 & 4 & 150 & 1996 & 70 \\
\hline 5 & 15.91 & 3 & 200 & 1997 & 70 \\
\hline 6 & 16.29 & 3 & 180 & 2001 & 70 \\
\hline 7 & 19.55 & 4 & 120 & 2009 & 80 \\
\hline 8 & 34.28 & 3 & 190 & 1990 & 70 \\
\hline 9 & 38.34 & 5 & 200 & 1999 & 70 \\
\hline 10 & 46.60 & 4 & 210 & 2008 & 80 \\
\hline $\begin{array}{l}\text { Average } \\
\text { value }\end{array}$ & 20.24 & 4 & 171 & - & - \\
\hline
\end{tabular}

source: own elaboration based on the conducted research.

The calculation methodology used included an algorithm to estimate the biomass demand from perennial energy crops that will cover the energy demand for social purposes of a residential building located on the farm under study. The algorithm also presented a method for estimating the theoretical area of energy crop cultivation from which biomass will cover the energy demand for social purposes.

The following initial assumptions were adopted for the calculations:

- the type of biomass that can be used for heating purposes on the farms under studyMiscanthus giganteus, Pennsylvania sida, energy willow;

- the agricultural holding has a residential building with a specific area to be heated, and the total needs of the holding for energy for heating (EG) include two components:

$$
E_{G}=E_{S}+E_{P}\left(M J \text { year }^{-1}\right)
$$


where: $E_{S}$ is energy for social purposes $\left(\mathrm{MJ} \mathrm{year}^{-1}\right)$, and $\mathrm{E}_{\mathrm{P}}$ is energy for production purposes $\left(\mathrm{MJ}\right.$ year $\left.{ }^{-1}\right)$;

- biomass from energy crops with an assumed calorific value will be used to heat the dwelling;

- the total annual energy demand for social purposes on the farm comprises:

$$
\mathrm{E}_{\mathrm{S}}=\mathrm{E}_{\mathrm{W}}+\mathrm{E}_{\mathrm{D}}\left(\mathrm{MJ} \text { year }^{-1}\right)
$$

where: EW is the annual energy demand for water heating $\left(\mathrm{MJ}\right.$ year $\left.{ }^{-1}\right)$, and $\mathrm{ED}$ is the annual energy demand for heating the house (MJ year ${ }^{-1}$ );

- energy used per year for water heating, calculated according to the formula:

$$
\mathrm{E}_{\mathrm{W}}=\mathrm{i} \cdot \mathrm{q} \cdot\left(\mathrm{T}_{\mathrm{C}}-\mathrm{T}_{\mathrm{Z}}\right) \cdot \mathrm{c}_{\mathrm{W}} \cdot 365\left(\mathrm{MJ} \mathrm{year}^{-1}\right)
$$

where: $\mathrm{I}$ is the number of persons in the holding (pcs.), $\mathrm{q}$ is daily hot water consumption (l/person), $\mathrm{T}_{\mathrm{C}}$ is hot water temperature $\left({ }^{\circ} \mathrm{C}\right), \mathrm{T}_{\mathrm{Z}}$ is cold water temperature $\left({ }^{\circ} \mathrm{C}\right)$, $\mathrm{C}_{\mathrm{W}}$ is specific heat of the water $\left(\mathrm{MJ} \mathrm{kg}{ }^{-1}\right)$, and 365 is the number of days per year;

- $\quad$ energy need for heating a residential building calculated using the formula:

$$
\mathrm{E}_{\mathrm{D}}=\mathrm{F} \cdot \mathrm{XE}\left(\mathrm{MJ} \text { year }^{-1}\right)
$$

where: $\mathrm{F}$ is the area to be heated $\left(\mathrm{m}^{2}\right), \mathrm{X}_{\mathrm{E}}$ is the energy consumption index $\left(\mathrm{MJ}\left(\mathrm{m}^{2} \text { year }\right)^{-1}\right)$;

- annual biomass demand to cover energy needs for social purposes:

$$
\left(\mathrm{t} \cdot \text { year }^{-1}\right)
$$

where: $Z_{B}$ is biomass demand $\left(t_{\text { year }}{ }^{-1}\right), E_{S}$ is energy for social purposes $\left(M J\right.$ year $\left.^{-1}\right), W_{E}$ - $\quad$ energy value of biomass $\left(\mathrm{MJ} \mathrm{kg}^{-1}\right), \eta$ is the boiler efficiency of the heating system (\%), 1000;

- conversion of requirements from kilograms to tonnes;

- $\quad$ the area under energy crops, from which the specific biomass yield $P_{\mathrm{js} . \mathrm{m} \text {. will cover }}$ the annual energy demand for social purposes:

(ha)

- daily hot water consumption $\mathrm{q}=801$ person $^{-1}$;

- hot water temperature $\mathrm{T}_{\mathrm{C}}=55^{\circ} \mathrm{C}$;

- cold water temperature $\mathrm{Tz}=10^{\circ} \mathrm{C}$;

- $\quad$ specific heat of water $\mathrm{c}_{\mathrm{W}}=4.19 \cdot 10-3 \mathrm{MJ}\left(\mathrm{kg} \mathrm{K}^{-1}\right)$;

- $\quad$ energy consumption index for a house built before $1998 \mathrm{X}_{\mathrm{E} 1}=1260 \mathrm{MJ}\left(\mathrm{m}^{2} \text { year }\right)^{-1}$ (CPPAI 2001);

- $\quad$ energy consumption index for a house built after $1998 \mathrm{X}_{\mathrm{E} 2}=432 \mathrm{MJ}\left(\mathrm{m}^{2} \text { year }\right)^{-1}$ (PN-91/B02020).

The costs of biomass production from energy crops were estimated using the computer application "Biobkalkulator", made by the employees of the Faculty of Production Engineering and Energy of the University of Krakow (The computer application "Biobcalculator" has been developed within the framework of the Ordered Research Project No. PBZ-MNiSW-1/3/2006 entitled: "Modern technologies of energetic use of biomass and biodegradable wastes $/ \mathrm{BiOB} /$ - conversion of $\mathrm{BiOB}$ to energy gaseous fuels". The application is available at: http://biob.wipie.ur.krakow.pl/biobkalk/ (accessed on 12 October 2021) [48].) [48], "Biobkalkulator" is an IT system for comprehensive advice on biomass production and processing as a substitute for conventional energy carriers used for heating purposes. It has a modular character, meaning that there are four separate modules in the application, which can be used by the user independently or in combination with others, i.e.,:

- Module 1: enabling an estimation of the energy demand for heating a building (conventional energy carriers or biomass) and producing an estimated energy audit for the building; 
- Module 2: enabling the estimation of the labour and energy cost of biomass production in field crops and the cost of biomass production and energy in biomass;

- Module 3: enabling the estimation of labour and energy cost for the production of compact biofuels (briquettes or pellets) from biomass;

- Module 4: containing a database of technical equipment for biomass production, processing, and combustion.

In this study, Module 2 was used to estimate biomass production costs, assuming a theoretical perennial energy crop plantation area and a dry biomass yield.

Biomass production costs were determined as the sum of plantation depreciation costs and harvesting costs. In turn, the plantation depreciation costs were calculated as the quotient of the plantation establishment costs and the planned lifetime of the plantation (i.e., 18 and 25 years). It should be stressed at this point that the costs of establishing willow plantations are still high, and among them, the costs of purchasing cuttings or hedgerows are a huge item. It is confirmed by other studies that the costs of establishing a willow plantation and the share of the cost of seedlings in their structure can be highly differentiated and are dependent on the applied planting density, the price of the planting material, and the applied agrotechnics [49-53]. In the Eko-Salix system, it is possible to reduce the costs of plantation establishment by obtaining hedgerows from their mother plantations and mechanising their planting. Moreover, it should be added that the costs of establishing a willow plantation significantly burdens the investor once at the beginning of the investment and freeze the financial resources, so to speak, which discourages undertaking this kind of activity [54]. Plantation establishment costs range from $1538 \mathrm{EUR} \mathrm{ha}^{-1}$ [14] to $1987 \mathrm{EUR} \mathrm{ha}^{-1}$ [52]. A similar situation is related to the costs of establishing Miscanthus giganteus and sida plantations, which are also high and burden the one-time investment in the establishment of plantations. The costs of establishing a Miscanthus giganteus plantation are on the level of $5105 \mathrm{EUR} \mathrm{ha}^{-1}$, and in the case of hay mallow, from $2150 \mathrm{EUR} \mathrm{ha}^{-1}$ to 2511 EUR ha ${ }^{-1}$ [31]. The costs of plantation establishment were assumed as constant values for ten plantations, separately for each of the specified plants. The assumptions for the calculations are presented in Table 2 .

The technical and operational parameters of the machinery used for harvesting Miscanthus giganteus, Sida hermaphrodita, and energy willow were determined based on data and standards indicated in the literature on the subject [49-55].

Table 2. Calculation assumptions for selected energy crops.

\begin{tabular}{ccccc}
\hline Description & Unit & Miscanthus Giganteus & Sida Hermaphrodita & Energy Willow \\
\hline Dry matter yield & $\mathrm{t} \mathrm{ha}^{-1}$ & 8 & 9 & 10 \\
\hline Calorific value & $\mathrm{MJ} \mathrm{kg}^{-1}$ & 17 & 2312 & 19 \\
\hline $\begin{array}{c}\text { Costs of establishing a } \\
\text { plantation }\end{array}$ & $\mathrm{EUR} \mathrm{ha}^{-1}$ & 4555 & 18 & 25 \\
\hline $\begin{array}{c}\text { Planned period of use } \\
\text { of the plantation }\end{array}$ & years & 18 & 128 & 71 \\
\hline $\begin{array}{c}\text { Plantation depreciation } \\
\text { costs }\end{array}$ & EUR (ha year) & & 174 \\
\hline
\end{tabular}

Source: Own elaboration based on [10,18,22,32,53,56].

Additional assumptions made for the calculations are:

- diesel oil price-1.15 EUR $1^{-1}$;

- $\quad$ price of baling twine-9.29 EUR $\mathrm{kg}^{-1}$;

- $\quad$ operator work costs-3.11 EUR rbh ${ }^{-1}$;

- labour costs for an assistant-2.43 EUR rbh ${ }^{-1}$;

- exchange rate of 1 EUR (on average according to the National Bank of Poland in 2020)-4.52 PLN;

- $\quad$ prices of tractors and machinery were averaged from the 1st quarter of 2020. 
Calculations and analyses were performed using descriptive statistics-the minimum value, the average value, the maximum value, and the standard deviation were considered.

\section{Technology of Harvesting Energy Crops}

A key stage in the production of energy crops is harvesting. Although the theoretical possibilities of using modern harvesting technologies are great, very different techniques of mowing and processing biomass are still used in practice. It applies primarily to Polish conditions, where the cultivation of energy crops is very dispersed. The areas of individual plantations are highly varied and range from several acres to several hundred hectares. Depending on the adopted harvesting technology, different machines are used, which may be equipped with units with installed shearing mechanisms, with specific functional features adapted to the type of plant and harvest cycle [51].

The technology of harvesting Miscanthus giganteus and mullein biomass in the form of straw compacted with a small-size baler (A) includes the stage of mowing with a rotary mower, baling, and transport, understood as loading and unloading manually. At the first stage, Miscanthus giganteus or mullein is cut into swaths, and then, at the second stage, the plant mass is compacted, which facilitates the transport of biomass. The technology of straw baling with small presses is used on small farms. The disadvantage of this type of baler is the relatively low capacity and higher labour requirement for straw transport and storage. The advantage is the universality of the balers and the low power requirement of the cooperating tractor. The main factors determining the cost of straw harvesting are the crop yield and harvesting method. As the yield increases, the cost per unit decreases. Straw harvesting with a small baler is the cheapest method due to low investment outlays and uncomplicated loading and transport. However, in the case of harvesting straw from larger areas, this technology is not efficient enough and requires relatively high labour input (Table 3).

Table 3. Miscanthus giganteus and mullein harvesting technology and machinery used in the surveyed agricultural holdings.

\begin{tabular}{|c|c|c|c|c|c|c|c|}
\hline \multirow{2}{*}{ Farm } & \multirow{2}{*}{$\begin{array}{c}\text { Harvesting Technology for } \\
\text { Miscanthus Giganteus and Sida } \\
\text { Hermaphrodita }\end{array}$} & \multicolumn{2}{|c|}{ Mowing } & \multicolumn{2}{|c|}{ Ironing } & \multicolumn{2}{|c|}{ Transport } \\
\hline & & Tractor & Mower & Tractor & Press & Tractor & Trailer \\
\hline 1 & $\mathrm{~A}$ & C330 & $\mathrm{Z} 125 / 2 \mathrm{~K}$ & C330 & Z511 & U4512 & D732 \\
\hline 2 & B & $\mathrm{C} 360$ & $\mathrm{Z} 070 / 1$ & C360 & $\mathrm{Z} 224 / 1$ & Z4320 & $\mathrm{T} 654$ \\
\hline 3 & A & U3514 & Z105/1 & U3514 & Z511 & U3514 & T058 \\
\hline 4 & $\mathrm{~B}$ & C360 & $\mathrm{Z} 070 / 1$ & C360 & $\mathrm{Z} 224 / 1$ & U4512 & D732 \\
\hline 5 & $\mathrm{~A}$ & $\mathrm{C} 360$ & $\mathrm{Z} 125 / 2 \mathrm{~K}$ & $\mathrm{C} 360$ & $\mathrm{Z} 224 / 1$ & $\mathrm{C} 360$ & T654 \\
\hline 6 & A & U3512 & Z125 & U3512 & Z511 & U3512 & T058 \\
\hline 7 & $\mathrm{~A}$ & $\mathrm{C} 360$ & Z175 & C360 & $\mathrm{Z} 224 / 1$ & U4512 & D732 \\
\hline 8 & A & Z5320 & ŻTR165 & Z5320 & $\mathrm{Z} 224 / 1$ & Z5320 & D732 \\
\hline 9 & $\mathrm{C}$ & $\begin{array}{c}\text { Pronar } \\
82 \mathrm{~A}\end{array}$ & Z010 & $\begin{array}{c}\text { Pronar } \\
82 \mathrm{~A}\end{array}$ & Z276 & $\begin{array}{c}\text { Pronar } \\
82 \mathrm{~A}\end{array}$ & $\mathrm{~T} 127$ \\
\hline 10 & $\mathrm{C}$ & Z5340 & ŻTR165 & Z5340 & Z581/1 & U6012 & $\mathrm{T} 150 / 1$ \\
\hline
\end{tabular}

Source: own elaboration based on the conducted research.

Harvesting straw that was compacted with a small-size baler with direct loading (B) comprises mowing with a rotary mower, baling of straw with direct loading (trailers used interchangeably, the so-called stream harvest) and manual unloading. Harvesting via this technological option is carried out depending on transport. The baler is equipped with a rear bale guide (the so-called longitudinal), which transfers the tied bales directly to the trailer attached to the rear baler. The bales are unloaded manually. Technology is also 
suitable for small farms. The main elements that determine the cost of straw harvesting are the yield and the harvesting method (Table 3).

In the technology of straw harvesting with a large-bale baler (C), at the first stage, Miscanthus giganteus or mallow (similarly to technologies A and B) is cut into swaths and then, at the second stage, plant matter is compacted. The technology of harvesting straw with balers allows for more straightforward and more complex mechanisation. Depending on the type of compaction chamber, there are variable, fixed, and mixed compactors. Furthermore, equipping the balers with a pre-compaction chamber approximately doubles the capacity. Straw harvesting with a round baler is carried out independently of transport, i.e., the baling procedure is carried out separately from the transport of the bales. The large size and weight of the bales do not allow for direct (step-by-step) harvesting of the straw onto transport vehicles. The main elements that determine the cost of straw harvesting are the yield and the harvesting method. As the yield increases, the cost per unit decreases. The use of modern high-capacity machines working in fields with a more extensive acreage can significantly reduce the costs (Table 3 ).

Willow felling with chainsaws (D) or combustion cutters (E) are the most popular harvesting technology methods of this plant in Poland. They consist of manually forming willow shoots into bundles, then manually loading, transporting, and again, manually unloading. For harvesting energy willow on small plantations, chainsaws or combustion cutters can be used. Both methods are ad hoc, have low productivity, require special care, and a trained work team to use the cutting equipment (Table 4).

Table 4. Energy willow harvesting technology and machinery used.

\begin{tabular}{|c|c|c|c|c|c|}
\hline \multirow[b]{2}{*}{ Farm } & \multirow{2}{*}{$\begin{array}{c}\text { Technology } \\
\text { of Harvesting Willow } \\
\text { Energy }\end{array}$} & \multicolumn{2}{|c|}{ Mowing (Harvesting) } & \multicolumn{2}{|c|}{ Transport } \\
\hline & & $\begin{array}{c}\text { Chainsaw } \\
\text { or Petrol-Driven Lawnmower }\end{array}$ & $\begin{array}{l}\text { Number of } \\
\text { People * }\end{array}$ & Tractor & Trailer \\
\hline 1 & $\mathrm{D}$ & Stihl MS230 & $1+2$ & U4512 & D732 \\
\hline 2 & $\mathrm{E}$ & Solo 142 & $1+2$ & C360 & T654 \\
\hline 3 & $\mathrm{D}$ & Stihl MS310 & $1+1$ & U3514 & T058 \\
\hline 4 & $\mathrm{E}$ & Stihl FS75X & $1+1$ & U4512 & D732 \\
\hline 5 & $\mathrm{E}$ & Solo 134 & $1+2$ & C360 & T654 \\
\hline 6 & $\mathrm{D}$ & Stihl MS270 & $1+1$ & U3512 & T058 \\
\hline 7 & $\mathrm{D}$ & Stihl MS230 & $1+2$ & U4512 & D732 \\
\hline 8 & $\mathrm{E}$ & Solo 142 & $1+2$ & Z5320 & D732 \\
\hline 9 & $\mathrm{D}$ & Stihl MS310 & $1+1$ & Pronar 82A & $\mathrm{T} 127$ \\
\hline 10 & $\mathrm{D}$ & Stihl MS390 & $1+2$ & U6012 & $\mathrm{T} 150 / 1$ \\
\hline
\end{tabular}

\section{Research Findings and Discussion}

Following the adopted research methodology, the analyses began with determining the energy demand in the studied agricultural holdings for the so-called social purposes. Within this category, the components have been distinguished, i.e., the energy needed to heat water consumed by the persons composing the farm and the energy needed to heat a residential building located in the farm has been determined. At the same time, the demand for biomass obtained from Miscanthus giganteus, Sida hermaphrodita, and energy willow was determined for each analysed unit (Table 5). The energy required to heat water was 22,573.2 $\mathrm{MJ} \mathrm{year}^{-1}$ on average for the farm, while the energy required to heat the house was $118,584.0 \mathrm{MJ}_{\text {year }}{ }^{-1}$ on average (which accumulated an energy demand of 141,157.2 $\mathrm{MJ}_{\text {year }}{ }^{-1}$ in total). The biomass demand, in turn, depended on the type of plant used for this purpose. Miscanthus giganteus was, on average, 11.5 tonnes year $^{-1}$ of dry mat- 
ter and for mallow, 13.1 tonnes year ${ }^{-1}$, while for energy willow it was 10.3 tonnes year ${ }^{-1}$.

Table 5. The demand for energy $\left(\mathrm{E}_{\mathrm{S}}\right)$ and biomass $\left(\mathrm{Z}_{\mathrm{B}}\right)$ in the studied agricultural holdings.

\begin{tabular}{|c|c|c|c|c|c|c|}
\hline \multirow{3}{*}{ Farm } & \multicolumn{3}{|c|}{ Energy for Social Purposes $\left(E_{s}\right)$} & \multicolumn{3}{|c|}{ Biomass Demand (Dry Matter) $\left(Z_{B}\right)$} \\
\hline & $\begin{array}{l}\text { Energy to Heat } \\
\text { Water }\end{array}$ & $\begin{array}{l}\text { Energy to Heat } \\
\text { Your Home }\end{array}$ & Total & $\begin{array}{l}\text { Miscanthus } \\
\text { Giganteus }\end{array}$ & $\begin{array}{c}\text { Sida } \\
\text { Hermaphrodita }\end{array}$ & Energy Willow \\
\hline & \multicolumn{3}{|c|}{$\left(\mathrm{MJ} \cdot \mathrm{Year}^{-1}\right)$} & \multicolumn{3}{|c|}{$\left(t \cdot\right.$ Year $\left.^{-1}\right)$} \\
\hline 1 & $27,528.3$ & $60,480.0$ & $88,008.3$ & 7.4 & 8.4 & 6.6 \\
\hline 2 & $33,034.0$ & $77,760.0$ & $110,794.0$ & 8.1 & 9.2 & 7.3 \\
\hline 3 & $22,022.6$ & $60,480.0$ & $82,502.6$ & 6.9 & 7.9 & 6.2 \\
\hline 4 & $22,022.6$ & $189,000.0$ & $211,022.6$ & 17.7 & 20.1 & 15.9 \\
\hline 5 & $16,517.0$ & $252,000.0$ & $268,517.0$ & 22.6 & 25.6 & 20.2 \\
\hline 6 & $16,517.0$ & $77,760.0$ & $94,277.0$ & 7.9 & 9.0 & 7.1 \\
\hline 7 & $22,022.6$ & $51,840.0$ & $73,862.6$ & 5.4 & 6.2 & 4.9 \\
\hline 8 & $16,517.0$ & $239,400.0$ & $255,917.0$ & 21.5 & 24.4 & 19.2 \\
\hline 9 & $27,528.3$ & $86,400.0$ & $113,928.3$ & 9.6 & 10.9 & 8.6 \\
\hline 10 & $22,022.6$ & $90,720.0$ & $112,742.6$ & 8.3 & 9.4 & 7.4 \\
\hline \multicolumn{7}{|c|}{ Basic descriptive statistics } \\
\hline Min. value & $16,517.0$ & $51,840.0$ & $73,862.6$ & 5.4 & 6.2 & 4.9 \\
\hline Average value & $22,573.2$ & $118,584.0$ & $141,157.2$ & 11.5 & 13.1 & 10.3 \\
\hline Max value & $33,034.0$ & $252,000.0$ & $268,517.0$ & 22.6 & 25.6 & 20.2 \\
\hline $\begin{array}{l}\text { Standard } \\
\text { deviation }\end{array}$ & 5475.0 & $77,249.3$ & $74,336.8$ & 6.4 & 7.3 & 5.8 \\
\hline
\end{tabular}

Source: own elaboration based on the conducted research.

A necessary measure complementing the above energy demand of the surveyed farms was calculating the theoretical area of cultivation of energy crops, from which biomass would cover the demand for energy used for social purposes. Depending on the energy demand of the studied farms related to the area of the residential building, the number of inhabitants and the technical condition of the heating system, the theoretical cultivation areas (Table 6) ranged from:

- $\quad 0.6$ ha-2.51 ha (average 1.28 ha) for giant Miscanthus giganteus,

- $\quad 0.88$ ha-3.65 ha (average $1.87 \mathrm{ha}$ ) for Sida hermaphrodita,

- $\quad 0.49$ ha-2.02 ha (average 1.03 ha) for energy willow.

The analyses carried out so far have provided a starting point for estimating biomass production costs from selected energy crops. Separate cost calculations have been made for each crop, including production costs and biomass harvesting costs. Biomass harvesting costs were divided into mowing and baling costs and transport costs. The plantation depreciation costs (assuming 18 years of plantation use), irrespective of the crop area, were assumed at a constant level of 253 EUR ha year ${ }^{-1}$ (Table 2). The obtained results indicated that in the case of Miscanthus giganteus, the costs of mowing and baling amounted, on average, in the studied holdings to $94 \mathrm{EUR} \mathrm{ha}^{-1}$. In comparison, the costs of transport were estimated at the average level of $78 \mathrm{EUR} \mathrm{ha}^{-1}$ (Table 7). On the other hand, the biomass production costs from Miscanthus giganteus amounted on average to $424.7 \mathrm{EUR}^{-1}$ (minimum 370.5 EUR ha ${ }^{-1}$, maximum 573.4 EUR ha ${ }^{-1}$ ). In turn, converted into tonne, it averaged 37.6 EUR $\mathrm{t}^{-1}$. For comparison, the costs of producing biomass from Miscanthus giganteus, according to other studies, amounted to $63 \mathrm{EUR} \mathrm{t}^{-1}$ [31].

Similar submissions concerning unit plantation depreciation costs were accepted in the case of Pennsylvania hogweed. Regardless of the cultivation area of this energy crop, they were at the same level of 128 EUR ha year ${ }^{-1}$ (Table 2). Based on obtained results from 
investigated agricultural holdings, the costs of mowing and pressing mulch straw were, on average, 89.5 EUR ha ${ }^{-1}$, ranging from $77.8 \mathrm{EUR} \mathrm{ha}^{-1}$ to $115.4 \mathrm{EUR} \mathrm{ha}^{-1}$ in agricultural holding No. 9. Transport costs, on the other hand, oscillated around the average level of 60.9 EUR ha ${ }^{-1}$. Total costs of biomass production from Pennsylvania mallow were, on average, 278.9 EUR ha ${ }^{-1}$ and $30 \mathrm{EUR} \mathrm{t}^{-1}$, ranging from 241.4 EUR to $361.1 \mathrm{EUR}$ per hectare and from 26.0 EUR to 38.8 EUR per 1 ton (Table 8). For comparison, the biomass production costs from mallow, according to other studies, were $73.2 \mathrm{EUR} \cdot \mathrm{t}^{-1}$ [31].

In the case of biomass production costs from energy willow, due to the applied harvesting technologies (i.e., technology D or E), the category of harvesting costs was narrowed down to components, including shearing costs (no baling costs) and transport costs. Unit plantation depreciation costs irrespective of the cultivation area were assumed at the same level of 71 EUR ha year ${ }^{-1}$ (Table 2), assuming harvesting occurs in a three-year rotation. On this basis, it was estimated that in the assessed agricultural holdings with diversified willow cultivation areas, the costs of felling in the form of whole shoots using circular saws and cutters amounted to $427.6 \mathrm{EUR} \mathrm{ha}^{-1}$. In comparison, the costs of biomass transport amounted to $113.5 \mathrm{EUR} \mathrm{ha}^{-1}$ (Table 9). The total costs of biomass production from energy willow per 1 hectare ranged from $485.4 \mathrm{EUR} \mathrm{ha}^{-1}$ to $725.8 \mathrm{EUR} \mathrm{ha}^{-1}$, amounting, on average, to 612.1 EUR ha ${ }^{-1}$. Converted into 1 tonne of biomass, it was, respectively: min. 24.3 EUR $t^{-1}$, max. The costs of biomass production from energy willow, according to other studies, were at the level of $42.2 \mathrm{EUR} \mathrm{t}^{-1}$ [31].

Table 6. Theoretical area of cultivation of selected energy crops.

\begin{tabular}{|c|c|c|c|}
\hline \multirow{2}{*}{ Farm } & \multicolumn{3}{|c|}{ Theoretical Cultivated Area (ha): } \\
\hline & Miscanthus Giganteus & Sida Hermaphrodita & Energy Willow \\
\hline 1 & 0.82 & 1.20 & 0.66 \\
\hline 2 & 0.91 & 1.32 & 0.73 \\
\hline 3 & 0.77 & 1.12 & 0.62 \\
\hline 4 & 1.97 & 2.87 & 1.59 \\
\hline 5 & 2.51 & 3.65 & 2.02 \\
\hline 6 & 0.88 & 1.28 & 0.71 \\
\hline 7 & 0.60 & 0.88 & 0.49 \\
\hline 8 & 2.39 & 3.48 & 1.92 \\
\hline 9 & 1.06 & 1.55 & 0.86 \\
\hline 10 & 0.92 & 1.34 & 0.74 \\
\hline \multicolumn{4}{|c|}{ Basic descriptive statistics } \\
\hline Min. value & 0.60 & 0.88 & 0.49 \\
\hline Average value & 1.28 & 1.87 & 1.03 \\
\hline Max. value & 2.51 & 3.65 & 2.02 \\
\hline Standard deviation & 0.72 & 1.04 & 0.58 \\
\hline
\end{tabular}

Source: own elaboration based on the conducted research. 
Table 7. Production costs of biomass from Miscanthus giganteus in the agricultural holdings under study.

\begin{tabular}{|c|c|c|c|c|}
\hline \multirow{3}{*}{ Farm } & \multicolumn{2}{|c|}{ Biomass Harvesting Costs } & \multirow{2}{*}{\multicolumn{2}{|c|}{$\begin{array}{c}\text { Production Costs } \\
\text { Biomass }\end{array}$}} \\
\hline & Mowing Costs & Transport Costs & & \\
\hline & \multicolumn{2}{|c|}{$\left(E_{U R} \mathbf{h a}^{-1}\right)$} & $\left(E^{\prime} h^{-1}\right)$ & $\left(E_{U R} t^{-1}\right)$ \\
\hline 1 & 94.7 & 66.2 & 414.1 & 36.6 \\
\hline 2 & 84.9 & 32.4 & 370.5 & 32.8 \\
\hline 3 & 103.9 & 60.7 & 417.8 & 37.0 \\
\hline 4 & 84.9 & 33.3 & 371.3 & 32.9 \\
\hline 5 & 83.0 & 68.5 & 404.7 & 35.8 \\
\hline 6 & 98.6 & 54.2 & 405.9 & 35.9 \\
\hline 7 & 82.5 & 66.2 & 401.9 & 35.6 \\
\hline 8 & 89.1 & 66.8 & 409.1 & 36.2 \\
\hline 9 & 119.8 & 200.4 & 573.4 & 50.7 \\
\hline \multirow[t]{2}{*}{10} & 97.0 & 128.0 & 478.1 & 42.3 \\
\hline & \multicolumn{3}{|c|}{ Basic descriptive statistics } & \\
\hline Min. value & 82.5 & 32.4 & 370.5 & 32.8 \\
\hline Average value & 93.8 & 77.7 & 424.7 & 37.6 \\
\hline Max. value & 119.8 & 200.4 & 573.4 & 50.7 \\
\hline Standard deviation & 11.7 & 50.5 & 60.0 & 5.3 \\
\hline
\end{tabular}

Source: own elaboration based on the conducted research.

To sum up, it should be stated that in the agricultural holdings from the Małopolska region selected for the study, the biomass from Miscanthus giganteus and Sida hermaphrodita was harvested in the compressed form. In contrast, the energy willow was harvested in the form of whole shoots. Taking the above into account, it should be assessed that the most favourable type of biomass used for heating purposes would be the biomass obtained from Sida hermaphrodita, for which production costs were the lowest and ranged from 241.4 EUR ha ${ }^{-1}$ to 361.1 EUR ha $^{-1}$. The least economically advantageous variant was the production of biomass from energy willow, for which production costs were the highest and ranged from $485.4 \mathrm{EUR} \mathrm{ha}^{-1}$ to $725.8 \mathrm{EUR} \mathrm{ha}^{-1}$ (Figure 1). The factor differentiating the costs of plantation management and the costs of biomass production from energy crops was the machinery park in the holding and the level of mechanisation of production. Machines used in the production of energy crops should be characterised by high efficiency and maximally reduce the share of manual work [56]. The conducted research also confirmed it. The machinery that was on the equipment of the analysed farms and its efficiency and the applied technology of biomass harvesting shaped the level of biomass harvesting costs. 
Table 8. Costs of production of biomass from Sida hermaphrodita in the investigated agricultural holdings.

\begin{tabular}{|c|c|c|c|c|}
\hline \multirow{3}{*}{ Farm } & \multicolumn{2}{|c|}{ Biomass Harvesting Costs } & \multirow{2}{*}{\multicolumn{2}{|c|}{$\begin{array}{c}\text { Production Costs } \\
\text { Biomass }\end{array}$}} \\
\hline & Mowing Costs & Transport Costs & & \\
\hline & \multicolumn{2}{|c|}{$\left(\mathrm{PLN} \mathrm{ha}^{-1}\right)$} & $\left(\right.$ EUR ha $\left.{ }^{-1}\right)$ & $\left(E_{U R} t^{-1}\right)$ \\
\hline 1 & 91.8 & 54.5 & 274.8 & 29.5 \\
\hline 2 & 80.4 & 32.4 & 241.4 & 26.0 \\
\hline 3 & 99.5 & 50.0 & 277.9 & 29.9 \\
\hline 4 & 80.4 & 33.3 & 242.2 & 26.0 \\
\hline 5 & 77.8 & 56.4 & 262.7 & 28.2 \\
\hline 6 & 94.2 & 50.2 & 272.8 & 29.3 \\
\hline 7 & 78.1 & 54.5 & 261.1 & 28.1 \\
\hline 8 & 84.7 & 55.0 & 268.2 & 28.8 \\
\hline 9 & 115.4 & 117.2 & 361.1 & 38.8 \\
\hline 10 & 92.6 & 105.3 & 326.4 & 35.1 \\
\hline \multicolumn{5}{|c|}{ Basic descriptive statistics } \\
\hline Min. value & 77.8 & 32.4 & 241.4 & 26.0 \\
\hline Average value & 89.5 & 60.9 & 278.9 & 30.0 \\
\hline Max. value & 115.4 & 117.2 & 361.1 & 38.8 \\
\hline $\begin{array}{l}\text { Standard } \\
\text { deviation }\end{array}$ & 11.8 & 28.1 & 37.3 & 4.0 \\
\hline
\end{tabular}

Source: own elaboration based on the conducted research.

Table 9. Production costs of biomass from energy willow.

\begin{tabular}{|c|c|c|c|c|}
\hline \multirow{3}{*}{ Farm } & \multicolumn{2}{|c|}{ Biomass Harvesting Costs } & \multirow{2}{*}{\multicolumn{2}{|c|}{ Biomass Production Costs }} \\
\hline & Shear Costs & Transport Costs & & \\
\hline & \multicolumn{2}{|c|}{ (PLN ha $\left.{ }^{-1}\right)$} & $\left(E^{\prime}\right.$ ha $\left.^{-1}\right)$ & $\left(E^{\prime} t^{-1}\right)$ \\
\hline 1 & 1737.2 & 502.7 & 566.5 & 28.3 \\
\hline 2 & 1483.1 & 468.2 & 502.7 & 25.1 \\
\hline 3 & 2244.1 & 410.3 & 658.3 & 32.9 \\
\hline 4 & 2058.3 & 502.7 & 637.6 & 31.9 \\
\hline 5 & 2003.6 & 468.2 & 617.9 & 30.9 \\
\hline 6 & 2157.6 & 412 & 639.5 & 32.0 \\
\hline 7 & 1737.2 & 502.7 & 566.5 & 28.3 \\
\hline 8 & 1391.5 & 481.6 & 485.4 & 24.3 \\
\hline 9 & 2244.1 & 694.5 & 721.1 & 36.0 \\
\hline 10 & 2272.9 & 687.1 & 725.8 & 36.3 \\
\hline \multicolumn{5}{|c|}{ Basic descriptive statistics } \\
\hline Min. value & 1391.5 & 410.3 & 485.4 & 24.3 \\
\hline Average value & 1933.0 & 513.0 & 612.1 & 30.6 \\
\hline Max. value & 2272.9 & 694.5 & 725.8 & 36.3 \\
\hline $\begin{array}{l}\text { Standard } \\
\text { deviation }\end{array}$ & 325.3 & 99.6 & 82.0 & 4.1 \\
\hline
\end{tabular}




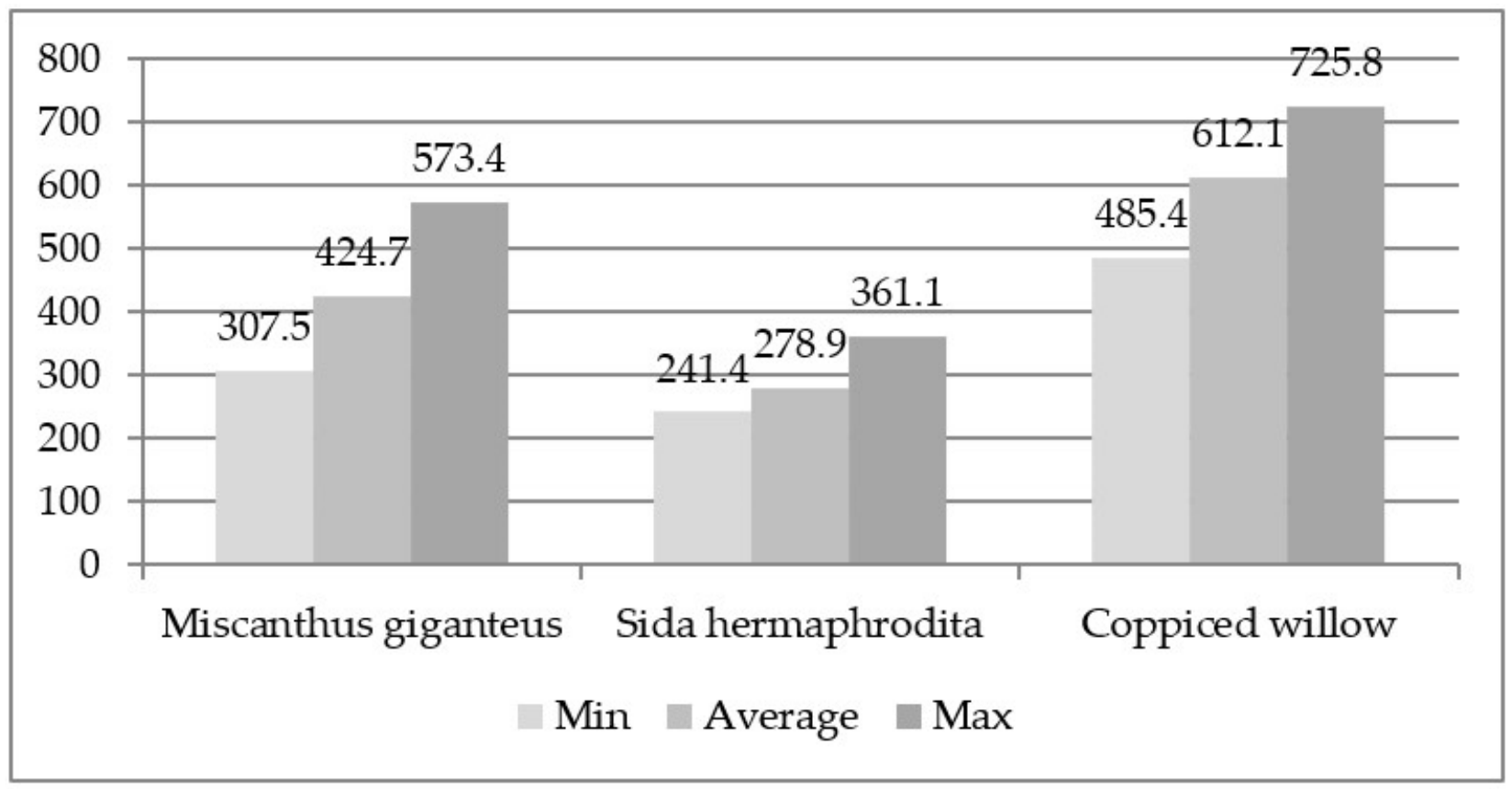

Figure 1. Comparison of biomass production costs from energy crops in EUR ha ${ }^{-1}$. Source: own elaboration based on the conducted research.

\section{Conclusions}

1. The level of demand for energy for social purposes in the studied agricultural holdings in the Małopolska region was estimated at an average of $141157 \mathrm{MJ}_{\text {year }}{ }^{-1}$. On the other hand, the demand for biomass from energy crops ranged from $10.3 \mathrm{t}_{\text {year }}{ }^{-1}$ (dry mass) for energy willow to $13.1 \mathrm{t}_{\text {year }}{ }^{-1}$ for Pennsylvania sida.

2. The theoretical area of cultivation of the analysed energy crops, from which the biomass obtained would cover the demand for energy used for social purposes in the studied agricultural holdings, should be 1.28 ha for Miscanthus giganteus, 1.87 ha for Pennsylvania mallow, and 1.03 ha for energy willow.

3. The Biobkalkulator computer application used for research is an added value and turned out to be a very helpful tool to estimate the cost of biomass production from selected perennial energy crops. However, it should be emphasized that an important role in its application is played by the input data obtained from farms selected for the research.

4. The costs of biomass production from energy crops in the agricultural holdings under study depended, to a considerable extent, on the harvesting technology used, the machinery used, and its efficiency. Regarding Miscanthus giganteus and Sida hermaphrodita, the harvesting was carried out using rotary mowers and small windrow balers. The costs of biomass production amounted to $424.7 \mathrm{EUR} \mathrm{ha}^{-1}$ for Miscanthus giganteus and 1260.5 278.9 EUR ha ${ }^{-1}$ for Sida hermaphrodita. In conversion per tonne, it was, respectively, 37.6 EUR t ${ }^{-1}$ for Miscanthus giganteus and $30.0 \mathrm{EUR}^{-1}$ for mullein.

5. In the case of harvesting energy willow in the form of whole shoots, inefficient and labour-intensive technologies using chainsaws and scythes were applied. It influenced the level of willow biomass production costs, which were the highest among the assessed plants and amounted, on average, to 612.1 EUR ha ${ }^{-1}$ and EUR $6 \cdot t^{-1}$.

6. The analysis presented in the paper and the results obtained may help in making a decision by potential owners of farms about cultivating perennial energy crops in order to produce biomass, taking into account the use of their own machinery for harvesting. 


\begin{abstract}
Author Contributions: Conceptualization: D.K. and A.P.; methodology: D.K.; software: D.K.; validation: D.K., A.P. and P.M.; formal analysis: A.P. and P.M.; investigation: D.K., A.P. and P.M.; resources: D.K.; data curation: D.K., A.P. and P.M.; writing—original draft preparation: D.K.; writing—review and editing: A.P. and P.M.; visualization: A.P.; supervision: P.M.; project administration: P.M.; funding acquisition: P.M. All authors have read and agreed to the published version of the manuscript.
\end{abstract}

Funding: This research received no external funding.

Institutional Review Board Statement: Not applicable.

Informed Consent Statement: Not applicable.

Data Availability Statement: Not applicable.

Conflicts of Interest: The authors declare no conflict of interest.

\title{
References
}

1. Chen, W.-H.; Budzianowski, W.; Lee, K.T. Preface-Sustainable Biofuels. Energy Convers. Manag. 2017, 141, 1. [CrossRef]

2. Dacko, M.; Płonka, A.; Satoła, Ł.; Dacko, A. Sustainable Development According to the Opinions of Polish Experts. Energies 2021, 14, 5325. [CrossRef]

3. BP Statistical Review of World Energy, British Petroleum 2019. Available online: https://www.bp.com/en/global/corporate/ energy-economics/statistical-review-of-world-energy.html (accessed on 17 September 2020).

4. The World Counts 2019. Available online: https://www.theworldcounts.com/ (accessed on 17 September 2020).

5. Bhaskar, T.; Bhavya, B.; Singh, R.; Naik, D.V.; Kumar, A.; Goyal, H.B. Thermochemical Conversion of Biomass to Biofuels. In Biofuels Alternative Feedstocks and Conversion Processes; Pandey, A., Larroche, C., Ricke, S.C., Dussap, C.G., Gnansounou, E., Eds.; Academic Press: Oxford, UK, 2011; pp. 51-77; ISBN 9780123850997.

6. Rosales-Calderon, O.; Arantes, V. A review on commercial scale high value products that can be produced alongside cellulosic ethanol. Biotechnol. Biofuels 2019, 12, 240. [CrossRef]

7. Marks-Bielska, R.; Bielski, S.; Pik, K.; Kurowska, K. The Importance of Renewable Energy Sources in Poland's Energy Mix. Energies 2020, 13, 4624. [CrossRef]

8. Ul Hai, I.; Sher, F.; Yaqoob, A.; Liu, H. Assessment of biomass energy potential for SRC willow woodchips in a pilot scale bubbling fluidised bed gasifier. Fuel 2019, 258, 116143. [CrossRef]

9. Dyrektywa Parlamentu Europejskiego i Rady 2009/28/WE z dnia 23 kwietnia 2009 r. w sprawie promowania stosowania energii ze źródeł odnawialnych zmieniająca i w następstwie uchylająca dyrektywy 2001/77/WE oraz 2003/30/WE (Dz.U. UE L 09.140.16). Available online: https:/ / eur-lex.europa.eu/legal-content/PL/TXT/PDF/?uri=CELEX:02009L0028-20151005\&from= GA (accessed on 17 September 2020).

10. Szczukowski, S.; Tworkowski, J.; Stolarski, M.; Kwiatkowski, J.; Krzyżaniak, M.; Lajszner, W.; Graban, Ł. Wieloletnie Rośliny Energetyczne; MULTICO Oficyna Wydawnicza: Warszawa, Poland, 2012; p. 156; ISBN 978-83-7763-051-8.

11. Rosenqvist, H.; Dawson, M. Economics of willow growing in Northern Ireland. Biomass Bioenergy 2005, 28, 7-14. [CrossRef]

12. Volk, T.A.; Abrahamson, L.P.; Nowak, C.A.; Smart, L.B.; Tharakan, P.J.; White, E.H. The development of short-rotation willow in the northeastern United States for bioenergy and bioproducts, agroforestry and phytoremediation. Biomass Bioenergy 2006, 30, 715-727. [CrossRef]

13. Stolarski, M.J.; Krzyżaniak, M.; Tworkowski, J.; Szczukowski, S.; Gołaszewski, J. Energy intensity and energy ratio in producing willow chips as feedstock for an integrated biorefinery. Biosyst. Eng. 2014, 123, 19-28. [CrossRef]

14. Tharakan, P.J.; Volk, T.A.; Lindsey, C.A.; Abrahamson, L.P.; White, E.H. Evaluating the impact of three incentive programs on co-firing willow biomass with coal in New York State. Energy Policy 2005, 33, 337-347. [CrossRef]

15. Kisiel, R.; Stolarski, M.; Szczukowski, S.; Tworkowski, J. Biomasa pozyskiwana z gruntów rolniczych źródłem energii. Zagad. Ekon. Rol. 2006, 4, 90-101.

16. Walle, I.V.; Van Camp, N.; Van de Casteele, L.; Verheyen, K.; Lemeur, R. Short-rotation forestry of birch, maple, poplar and willow in Flanders (Belgium) I-Biomass production after 4 years of tree growth. Biomass Bioenergy 2007, 31, 267-275. [CrossRef]

17. Grzybek, A. Zapotrzebowanie na biomase i strategie energetycznego jej wykorzystania. Studia I Rap. IUNG-PIB 2008, 11, 9-23. [CrossRef]

18. Kuś, J.; Faber, A.; Stasiak, M.; Kawalec, A. Produkcyjność wybranych gatunków roślin uprawianych na cele energetyczne w różnych siedliskach. Studia I Rap. IUNG-PIB 2008, 11, 68-80.

19. Dubas, J. Wierzba. In Rośliny Energetyczne; Kościk, B., Ed.; Wydawnictwo AR w Lublinie: Lublin, Poland, 2003 ; pp. 56-78.

20. Król, K. Wierzba wiciowa-Cenna roślina energetyczna. Tech. Rol. Ogrod. Leśna 2004, 3, 18-22.

21. Godet, J.D. Przewodnik Do Rozpoznawania Drzew I Krzewów; Oficyna Wydawnicza „Delta” W-Z: Warszawa, Poland, 2000; p. 255; ISBN 9788371758812.

22. Szczukowski, S.; Tworkowski, J.; Stolarski, M. Wierzba Energetyczna; Wydawnictwo Plantpress: Kraków, Poland, 2004; p. 46; ISBN 83-85982-86-8 
23. Dubas, J.W.; Tomczyk, A. Zakładanie, Pielęgnacja I Ochrona Plantacji Wierzb Energetycznych; Wydawnictwo SGGW: Warszawa, Poland, 2005; pp. 29-30.

24. Jasiulewicz, M. Efektywność ekonomiczna uprawy wierzby na gruntach marginalnych i możliwości wykorzystania biomasy w energetyce rozproszonej. In Ekonomiczne Uwarunkowania Stosowania Odnawialnych Źródeł Energii; Wydawnictwo Wieś Jutra: Warszawa, Poland, 2009; pp. 92-101.

25. Szczukowski, S.; Tworkowski, J. Produktywność wierzb krzewiastych Salix sp. na glebie organicznej. Inżynieria Ekol. 2000, $1,138-144$.

26. Szczukowski, S.; Tworkowski, J. Produktywność oraz wartość energetyczna biomasy wierzb krzewiastych Salix sp. na różnych typach gleb w pradolinie Wisły. Postępy Nauk. Rol. 2001, 2, 30-39.

27. Szczukowski, S.; Tworkowski, J. Plantacje energetyczne wierzby i innych roślin wieloletnich. Wieś Jutra 2004, 3, 53-55.

28. Borkowska, H.; Styk, B. Ślazowiec Pensylwański. In Rośliny Energetyczne; Kościk, B., Ed.; Wydawnictwo AR w Lublinie: Lublin, Poland, 2003; pp. 79-95.

29. Borkowska, H.; Styk, B. Ślazowiec Pensylwański (Sida Hermaphrodita Rusby). In Uprawa I Wykorzystanie; Wydawnictwo AR w Lublinie: Lublin, Poland, 2006; p. 69.

30. Kowalczyk-Juśko, A. Przydatność Wybranych Gatunków Roślin Do Energetycznego Wykorzystania. In Biomasa Jako Źródło Energii; Jackowska, I., Ed.; Wydawnictwo Wieś Jutra: Warszawa, Poland, 2009; pp. 39-50.

31. Kuś, J.; Matyka, M. Uprawa Roślin Na Cele Energetyczne; IUNG-PIB: Puławy, Poland, 2010; p. 64; ISBN 978-83-7562-072-6.

32. Faber, A.; Kuś, J.; Matyka, M. Uprawa Roślin Na Potrzeby Energetyki; W\&B Wiesław Krzewiński: Warszawa, Poland, 2009 ; p. 30.

33. Roszewski, R. Miskant Olbrzymi-Miscanthus Giganteus Sinensis Giganteus. In Nowe Rośliny Uprawne Na Cele Spożywcze, Przemystowe I Jako Odnawialne Źródła Energii; Wydawnictwo SGGW: Warszawa, Poland, 1996; pp. 123-135.

34. Majtkowska, G.; Majtkowski, W. Trawy Źródłem Energii. In Trawy I Rośliny Motylkowe; Wydawnictwo Biznes-Press Sp. z o.o. Warszawa: Warszawa, Poland, 2005; pp. 94-97.

35. Sawicki, B.; Kościk, K. Trawy I Zbiorowiska Trawiaste. In Rośliny Energetyczne; Kościk, B., Ed.; Wydawnictwo AR w Lublinie: Lublin, Poland, 2003; pp. 111-135.

36. Kozak, M. Możliwości uprawy i wykorzystania miskanta olbrzymiego na cele energetyczne w Polsce cz. I. Ekonatura 2006, 4, 18.

37. Igliński, B.; Buczkowski, R.; Cichosz, M. Technologie Bioenergetyczne; Wydawnictwo Naukowe Uniwersytetu Mikołaja Kopernika: Torun, Poland, 2009; p. 318; ISBN 978-83-231-2441-2.

38. Lisowski, A. Technologie Zbioru Roślin Energetycznych; Wydawnictwo SGGW: Warszawa, Poland, 2010; ISBN 978-83-7583-222-8.

39. Kwaśniewski, D. Modelowe technologie zbioru a koszty produkcji biomasy z trzyletniej wierzby energetycznej. Inżynieria Rol. 2011, 4, 167-176.

40. Kwaśniewski, D. Koszty i opłacalność produkcji biomasy z trzyletniej wierzby energetycznej. Inżynieria Rolnicza 2011, 15, 145-154.

41. Matyka, M. Produkcyjne I Ekonomiczne Aspekty Uprawy Roślin Wieloletnich Na Cele Energetyczne; Wydawnictwo IUNG-PIB: Puławy, Poland, 2013; pp. 1-94.

42. Styles, D.; Thorne, F.; Jones, M.B. Energy crops in Ireland: An economic comparison of willow and Miscanthus giganteus production with conventional farming systems. Biomass Bioenergy 2007, 32, 5. [CrossRef]

43. Nordborg, M.; Berndes, G.; Dimitriou, I.; Henriksson, A.; Mola-Yudego, B.; Rosenqvist, H. Energy analysis of willow production for bioenergy in Sweden. Renew. Sustain. Energy Rev. 2018, 93, 473-482. [CrossRef]

44. Frączek, J.; Cieślikowski, B.; Juliszewski, T.; Kwaśniewski, D.; Kuboń, M.; Kurpaska, S.; Mudryk, K.; Szeląg-Sikora, A.; Wójcik A.; Wróbel, M. Ekonomiczno-Organizacyjne Aspekty Produkcji Biopaliw; Wydawnictwo PTIR: Kraków, Poland, 2014; p. 181; ISBN 978-83-64377-02-0.

45. Ericsson, K.; Rosenqvist, H.; Ganko, E.; Pisarek, M.; Nilsson, L. An agroeconomic analysis of willow cultivation in Poland. Biomasy Bioenergy 2006, 30, 16-27. [CrossRef]

46. Cupiał, M.; Szelag-Sikora, A.; Niemiec, M. Farm. Machinery and Processes Management in Sustainable Agriculture, Huyghebaert, B., Lorencowicz, E., Uziak, J., Eds.; Department of Machinery Exploitation and Management of Production Processes University of Life Sciences in Lublin: Lublin, Poland, 2015; pp. 64-69.

47. Kowalczyk, Z.; Cupiał, M. Contemporary Research Trends in Agricultural Engineering BIO. Web. Conf. 2018, 10, 01011. [CrossRef]

48. BiOBkalkulator. Available online: http://biob.wipie.ur.krakow.pl/biobkalk/ (accessed on 12 October 2021).

49. Lorencowicz, E. Poradnik Użytkowania Techniki Rolniczej W Tabelach; Agencja Promocji Rolnictwa i Agrobiznesu: Bydgoszcz, Poland, 2007; p. 68; ISBN 83-91453-7-8.

50. Muzalewski, A. Koszty Eksploatacji Maszyn; ITP Falenty: Warszawa, Poland, 2010; p. 34.

51. Hutsol, T.; Yermakov, S.; Firman, J.; Duganets, V.; Bodnar, A. Analysis of Technical Solutions of Planting Machines, Which Can Be Used in Planting Energy Willow. In Renewable Energy Sources: Engineering, Technology, Innovation. Springer Proceedings in Energy; Wróbel, M., Jewiarz, M., Szlęk, A., Eds.; Springer: Cham, Switzerland, 2018. [CrossRef]

52. Sadowski, A.; Jankowiak, J.; Bieńkowski, J. Ekonomiczna efektywność uprawy wierzby. Fragm. Agron. 2007, 4, 153-159.

53. Matyka, M. Opłacalność i konkurencyjność produkcji wybranych roślin energetycznych. Studia I Rap. IUNG-PIB 2008, 11, 113-123.

54. Stolarski, M.; Szczukowski, S.; Tworkowski, J. Ekonomiczne aspekty produkcji biomasy wierzby w systemie Eko-Salix. Rocz. Nauk. Rol. 2010, 97, 82-89. 
55. Stolarski, M.J.; Szczukowski, S.; Tworkowski, J.; Krzyżaniak, M. Koszty założenia polowych plantacji szybko rosnących roślin drzewiastych. Rocz. Nauk. Rol. 2012, 99, 129-140.

56. Matyka, M. Opłacalność I Konkurencyjność Produkcji Roślin Energetycznych. In Odnawialne Źródła Energii. Rolnicze Surowce Energetyczne; Kołodziej, B., Matyka, M., Eds.; Powszechne Wydawnictwo Rolnicze i Leśne: Poznań, Poland, 2012; pp. 407-416; ISBN 978-83-09-01139-2. 